\title{
Yoruba Epistemology, Art, Language and the Universe of Meanings: A Meta-Analy- sis
}

\author{
Michael O. Afolayan \\ Independent Researcher \\ Òșogbo, Nigeria \\ mafolayan@yahoo.com
}

\section{Introduction}

I had the rare privilege of delivering in proxy the original paper of Professor Moyo Okediji at the African Studies Association meeting, where it was first presented on December 2, 2016.

Although short in quantity, I consider it to be loaded in quality, contents, intents, intensities, and in its ability to problematize a discourse critical to our understanding of indigenous scholarship and all its epistemological implications that span the entire landscape of the humanities. Indeed, Okediji's pedagogy is the proverbial Yoruba drum of "ogidigbó" which is revealed only to the wise and the prudent, and they are the only two capable of effectively dancing to its rhythm. The paper reminds one of the title of the memoir of Ellen DeGeneres, the famous American comedian, titled Seriously... I'm Kidding. Even as a non-apologist of Ellen DeGeneres, or of any other American comedian for that matter, one would find profound meaning to that title, and embrace it as very deep and philosophical. Like in many Shakespearean plays, many truths are expressed in the acts of the jesters, not in the court of the privileged kings and pundits. This is exactly the way I responded to Okediji's beautiful write-up. It got me thinking. It is a needed shock therapy, an organic rendition of an intellectual exposition of the Yoruba art. This commentary is janus-faced. On one hand, it looks at the unique way in which Moyo Okediji critiqued the work of Rowland Abiodun, Yoruba Art and Language: Seeking the African in African Art. On the other, it concurs with Abiodun's thesis of the indispensability of the Yoruba language and oral tradition in the understanding of the Yoruba art. 
In his contribution to the roundtable forum on Professor Abiodun's book at the African Studies Association in Washington, DC (December 1-3, 2016), Okediji provided his full presentation in Yoruba language, unalloyed (see the first essay in this forum). In order to broaden the scope of his readership and audiences, I chose to translate his write-up to the English language (Appendix 1). However, I used the translation to underscore the challenges of inter-cultural interpretation. The translation process demonstrates the problem of using one language to dissect another language without the depth of knowledge of the cultural make-up of the originator of the text. The attempt provides the data in which we are able to draw conclusions on a variety of issues: One, it highlights the futility of translation of a cultural theme at any level; two, it speaks to the frustration inherent in the imposition of one language over the art and culture of another; and three, it demonstrates the need for a cultural understanding between the originator of a text and the translator as precluding any reasonable translation and/or interpretation of the text. Using my attempt at translating as an example, I argue that at the very best what my effort could produce was an interpretation rather than a translation of Okediji's text. I then argue that Okediji's text brings to light the main thrust of Abiodun's argument, which is that the indigenous language that births the art and culture of a people is the only channel through which the said art and culture could be most accurately interpreted or critiqued. Any attempt at superimposing other languages on the art can only result in a secondary, if not tertiary, interpretation and consequently a watered-down version of the original. The corollary is that such attempt will of necessity tamper with the sacred epistemological authenticity of the language-art-culture continuum.

\section{Implications}

In his liberation theology, Paulo Freire $(1993,1994,1997)$ talks about "naming the world" as central to empowerment and total liberation. His notion of naming the world is the need for the individuals to be themselves, in control of their lives, to know who they are and have a deeper understanding of the space they occupy and the dialogue in which they engage within that space. Those who are able to name their worlds are functionally literate of their own culture, spatially, intellectually, emotionally, and psychologically. But the salient question, as Freire would want to ask, is this: how could one name one's world in the words of another person? This is a contradiction, Freire would argue. In essence, this is what Okediji problematizes in his critique. The critical issue taken up by the paper is whether or not it is at all possible to present and/or critique the art of the people of Africa and do so comfortably in the language or languages of others, especially the art of the Yoruba. Okediji is 
saying, emphatically, it is not possible. In his "meta-analysis", he captures the essence of what the seminal work of Professor Rowland Abiodun is all about.

\section{Applications}

I use Okediji's problematization as the launching pad for my own perspective on this matter. Indeed, in my endnote, I have reproduced verbatim my translation (or shall we call it interpretation?) of Okediji's essay (Appendix 1). His contribution effectively illuminates Professor Abiodun's argument albeit in a humorous but serious way, which he expressed in the context of Yoruba rhetoric. I will follow suit with Okediji by invoking the Swahili saying, Titi la mama li tamu. Literally, it means, "Mother's breast is what is sweet," a direct equivalent of Yoruba's "Omú iyá dìn." In a more functionally applicative and metaphorically applicable way, it means nothing is more nutritious, beneficial, authentic, or enduring to the health of the suckling baby than the mother's milk. In other words, the organic quality of the mother's milk lends authenticity to the rightness of the child's meal.

Let us bring that native intelligence into the ongoing conversation that Professor Abiodun has engendered, and which Okediji has accentuated here. There is no language anywhere, any time, which could deliver a meaningful explanation regarding any aspect of any culture in a healthier and more authentic manner than the language from which that culture emanates. This is a fact that has been proven in literatures of language, culture and anthropology. Indeed, the argument has been advanced that a child will learn a whole lot more when the instruction is based on the language of the mother because not only does it enhance cognition, it transmits the nuances contained within the scope of the culture of the knowledge being transmitted (see Emmitt and Pollock, 1997).

The popular Whorf-Sapir hypothesis goes further in extrapolating the matter of the marriage between language and culture (see Ahearn, 2011). It makes it clear that to gain a deeper insight into any culture or a cultural artifact, the investigator must have a deeper understanding, not only of the language, but also even of the grammar of the language. According to this hypothesis, it is inside the language that we find the culture and it is in the culture that we see the language - you cannot have one without the other. Yoruba art and language speak to the seriousness and authenticity of this theoretical framework.

Even of more importance and relevance to the ongoing discourse is the indubitable argument of O.B. Yai (1993) on the salience of the connection of language/oral tradition and a meaningful interpretation of Yoruba art, whether we are dealing with visual, verbal, aesthetic, performing, or any aspect of the art for that matter. In what follows, I provide an extended line of reasoning of Yai to elaborate my position: 
When approaching Yoruba art, an intellectual orientation that would be more in consonant with Yoruba tradition of scholarship would be to consider each individual Yoruba art work and the entire corpus as oriki... making oriki tutelary goddess of Yoruba art history studies enjoins us to pay more attention to the history dimension of the discipline's title. This in turn entails that we familiarize ourselves with Yoruba concepts of history and be conversant with the language and metalanguage of Yoruba art history...

For a Yoruba intellectual oriki as a concept and a discursive practice is inseparable from the concept and discursive practice of itan ... An exploration of the concept based on its linguistic analysis therefore is in order. This is no idle exercise, for the Yoruba word itan is invariably translated as "history," a word and concept with so vast a meaning as to deserve the appellation of "continent histoire" (continent history) in contemporary European discourse. (107)

Yai's point is well taken. It is in perfect alignment with Paulo Freire's position of "naming the world" and the Whorf-Sapir hypothesis that places language and culture in an unbreakable continuum. An interpretation or appreciation of a Yoruba art form rests heavily on the knowledge of the language and its cultural nuances, including its oral tradition. Dependency on foreign language to interpret the Yoruba art is giving the proverbial baby of the Obà River to the riverine goddess of O̦sun. The outcome cannot be good. The interpretation cannot be right, all because there exists a converse relationship between the two. There exists a clear contradiction in terms. What is lost in the process of interpretation is critical. In one of his footnotes to the conversation, Yai further elucidates the dilemma inherent in the contradiction, the silver lining being in the efforts of Yoruba art scholars to reverse the trend:

We are all victims of the imperialism of writing with its pejorative attitude towards oral cultures. As a consequence, more Africans conduct their research with an implicit assumption of a discursive and metalinguistic tabula rasa in the cultures being studied. The epistemological poverty of this attitude need not be elaborated. Fortunately, Yoruba art scholars are increasingly going against the grains, resulting in more perceptive analyses. (114)

Thus, looking through the 386 pages of Professor Abiodun's book and taking even a closer look at the 146 images in the book, one could not but ask how anyone could possibly understand, or appreciate, let alone appraise most, if not all, of the images, concepts and the poetics imbedded into the work if they are not immersed in the culture and language, especially the oral traditions, of the Yoruba. No doubt, in the absence of the depth of such knowledge 
this would pose a difficult proposition. In what follows, therefore, out of a preponderance of visual evidence contained in Abiodun's book, I have picked out two images for further discussion.

\section{The Visual, the Verbal, and the Aesthetic}

Let us examine the images on page 86 of Abiodun's book.

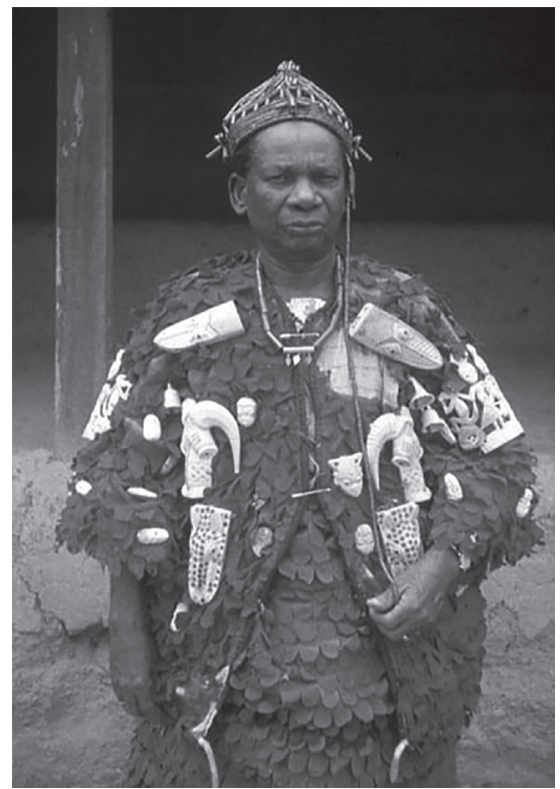

Figure 1a: The Ojomo of Ijebu-Owo wearing his Orufanran ceremonial war costume (front view)

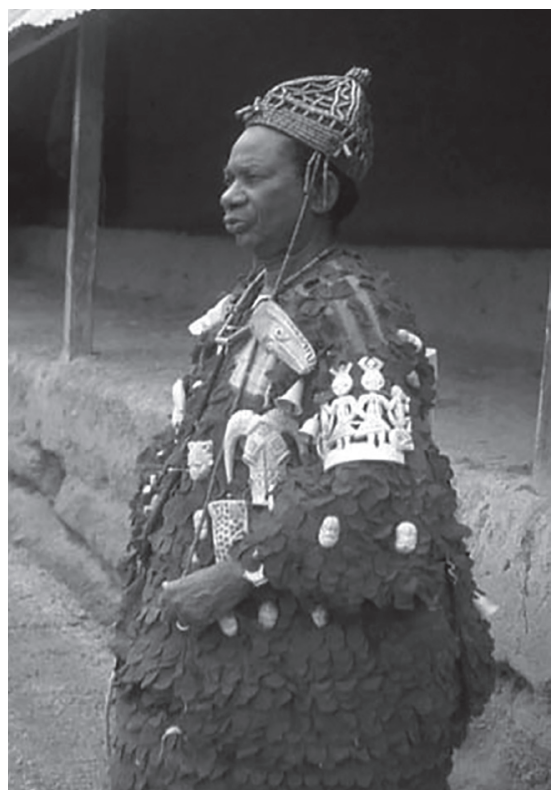

Figure 1b: The Ojomo of Ijebu-Owo wearing his Orufanran ceremonial war costume (side view)

The front and the side views of the image given the caption, "Ojomo of Ijebu-Owo wearing his Orufanran ceremonial war costume." The immediate question is how do I see this image or how does anyone appraise it? The average person who is not Yoruba sees a man standing with the regalia of a manof-war or a war commander. The color is red with charms hanging on the clothing. This description should be okay but it falls miserably short of its cultural intensity. As someone literate in Yoruba culture, when I see this image, I am immediately taken to the axiom, "A-bi-gbogbo-ara-kiki-oògùn" (He whose body is arrayed with the overwhelming presence of charms), or "Okùnrin ogun" (Man of war, the macho), or "Lógun l'Ékòó" (He who brings war all the way to Lagos - Lagos, being a euphemism for the sea; an amphibious fighter, 
a war hero, so to say). In other words, a surface understanding cannot do justice to the analysis of the image; it takes both the visual and wholesale cultural and linguistic understanding to be able to gain a deeper insight into the whole knowledge loaded into the single image.

Similarly, the image on page 169, partially titled "Gbáriye Onígba Awe " is worth being looked into.

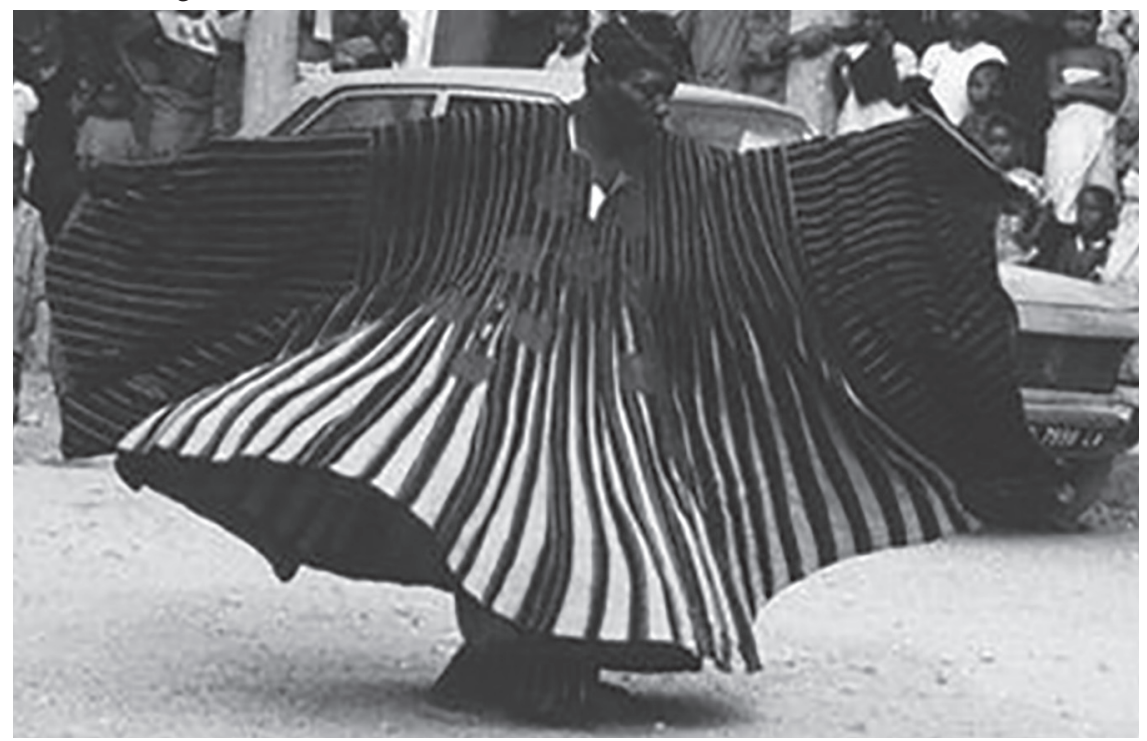

Figure 2: Gbárìyẹ Onígba Awẹ

It takes someone with more than just a casual acquaintance with the Yoruba language and culture to appreciate the dance of Baba Labe, the "rainbow coalition" of colors, the name of the clothing, and the totality of the configuration of the image, including the linguistic, the cultural, the aesthetic, the panoramic, etc., to appreciate the art form. For example, as a student of Yoruba language and tradition, the first thing that comes to mind as I see this image is the adage that, "Afọ́nú-fọ́ra ní ń fi òși jó bàtá." It simply means that the dance to the rhythm of the bàtá drum is not for the spiritually and materially bankrupt. This is quite clear in the image portrayed by the appearance of the dancer, Baba Labe. To the Yoruba eye, this dancer looks prosperous, confident, competent, dignified and spiritually endowed. Besides this, when I see this image, I am also intuitively thinking of the Yoruba praise epithet, "a-gùntásoó-lò" (a full body fellow, whose presence is capable of announcing, carrying or portraying the beauty of clothing). Words and phrases like "gbáriye ," "onígba awẹ," "agùn-tásṣoọ-lò," "k'ẹlẹ́nu-sọ́nu," etc., that configure this image, are loaded with meaning and located in various grammatical categories of 
Yoruba language. Those words include, "gbá" (verb), "riyẹ" (adverb), "gbáriye " (noun), "igba" (200 - number), "awẹ" (split - noun), "gùn" (tall - adjective), "gùn...tó lò" (split verb), "aṣọ" (cloth - noun).

Apart from these semantic distinctions that are loaded into the image, there are other facets of important cultural knowledge secondarily attached to the identified images. For example, there are words like agbo (the performance circle), ijó (dance), iran (spectacle), àrà (dazzling performance), àjàò (the flying rodent), etc. These are some of the artifacts of Yoruba epistemology that are necessary for evaluating this image. The name of the clothing style, "Igba Awẹ" (200 stripes) itself is material for analysis as 200 stripes is the metonymic representation of "many" in the context of Yoruba rhetoric and number formations. It simply implies that there are many stripes that make up the total configuration of the cloth. I wonder how anyone could understand this when such person is basing his or her analysis of the same image purely on the visual impression and textbook knowledge of Yoruba art. The epistemological nuances certainly go beyond the peripheral level of understanding.

Again, in agreement with Moyo Okediji, these are the issues that this book is highlighting and it is for such purpose that it provides an alternative narrative to what we call the "two-by-four" notion of scholarship in the study of Africa. This "two-by-four" notion is the pedagogical anomaly where the source of knowledge production of the scholar is totally dependent on the two covers of the textbook and/or the four corners of the classroom. This may work in some quarters but it is simply not a sustainable model in the study of Yoruba art where the epistemological package is loaded with a compendium of oral tradition, language, cultural codes and data outside the framework of western epistemology. Whether in its semantic or etymological construct or by virtue of its versatility or multiplicity in forms, the Yoruba art is complex (see, for example, Adesanya, 2016, and Famule, 2016). To capture its essences requires a depth of understanding of its cultural framework. No language is capable of getting to the bottom of this framework adequately and meaningfully if it is not Yoruba.

As a lifelong student of Yoruba and a native speaker of the language, my attempt to translate Okediji's text highlighted certain facts. One, all I could do was approximate Okediji's text; I could not reproduce the totality of his intellectual thinking. Two, that I was even able to render a version of his text and provide a meaningful textual end-product was possible only because of my knowledge of the cultural frame of reference in Okediji's writing. Yet, much was lost in translation and the end-product was not the original text, a classical case of the output becoming the mirror image of the input. This limited result would be further limited when the interpreter does not possess the cultural knowledge of the artist or of the art being interpreted. 


\section{Conclusion}

Having said all that, I conclude this write-up by invoking one of the cultural "scares" of the Yoruba, which is for anyone to be likened to a highway robber who snatches away the goods that belong to someone else, a deep verbal rebuke often reserved for an ungrateful person. Therefore, even in spite of its limited capability to convey the true meaning of the Yoruba art, acknowledgement must still be given to the role of foreign languages, especially the English language, in exposing the Yoruba art to the larger world. Glorious reputations should therefore be accorded the likes of Ulli Beier, Suzanne Wenger, Robert Farris Thompson, Henry Drewal, Margaret Thompson, John Pemberton III, and a host of others who have given a wider exposure to the Yoruba art. In the actual fact, the production of this seminal work of Abiodun is in the English language. But the challenge is staring us right in the face. The narrative needs to change. The Yoruba language, including and especially its oral tradition, and culture are the inseparable window through which we can gain a sneak peak behind the veil of the unquestionably rich, versatile and well endowed Yoruba art and its cultural components. Anything less than that may end up giving us at the very best a caricature of the art. This, in essence, is the primary issue this book has raised and done so in an exceptional fashion.

\section{References}

Abiodun, R. (2014). Yoruba Art and Language: Seeking the African in African Art. Cambridge: Cambridge Press.

Adesanya, A. A. (2016). “Art: Contemporary." In Encyclopedia of the Yoruba, edited by Toyin Falola and Akintunde Akinyemi. Bloomington \& Indianapolis, IN: Indiana University Press.

Ahearn, L. M. (2011). Living Language: An introduction to Linguistic Anthropology. Hoboken, NJ: John Wiley \& Sons.

Emmitt M. \& Pollock J. (1997). Language and learning: an introduction for teaching, $2^{\text {nd }}$ ed. Melbourne: Oxford University Press.

Famule, O. (2016). “Art: Indigenous.” In Encyclopedia of the Yoruba, edited by Toyin Falola and Akintunde Akinyemi. Bloomington \& Indianapolis, IN: Indiana University Press.

Freire, P. (1993). Pedagogy of the Oppressed. New York, Continuum.

Freire, P. and A.M.A. Freire (1994). Pedagogy of hope: reliving Pedagogy of the oppressed. New York, Continuum.

Freire, P. and A.M.A. Freire (1997). Pedagogy of the heart. New York, Continuum. 
Okediji, M. (2016). Elẹ́nu Ríri ati A a mu I yá Re. Paper Presented at the $59^{\text {th }}$ Annual African Studies Association Conference Washington, DC December 1-3, 2016

Yai, O. B. (1993). In Praise of Metonymy: The Concepts of "Tradition" and "Creativity" in the Transmission of Yoruba Artistry over Time and Space, Research in African Literature, 24(4), Special Issue in Memory of Josaphat Bekunuru Kubayanda, pp 29-37.

\section{APPENDIX 1}

A Translation of Moyọ Okediji's “ẸLẹnu Rírì àti Àmù Iyá Rẹ”" [The Art of Critiquing the Yoruba Art]

Translated and Read by Michael O. Afolayan

at the 59th Annual African Studies Association Conference, Washington, DC

December 1-3, 2016

\section{Translator's Preamble}

Our elders say, "Duty demands that you honor the one who sends you on an errand, more than fear the one to whom the message is delivered." The same elders also say, the sense of duty is this: when sent on an errand of bondage, you deliver it with the spirit of the freeborn. Why this preamble? It is because what I am about to deliver on behalf of my colleague, Dr. Moyo Okediji, has been deliberately crafted in the classical language of the people on which the book focuses - the Yoruba. Okediji requested specifically that this critique be delivered in Yoruba unalloyed and that no interpretation needs be offered. As a well-deserved honor to him who sent me, therefore, I will definitely do that. However, two things have precipitated a partial departure from an aspect of the message. One is that I am duty-bound to deliver my colleague's message with the "spirit of the freeborn," and two, Okediji's message is, in most essential ways, the quintessential Yoruba version of what I had prepared to deliver as my own part to the debate. So as not to re-invent the wheel, therefore, I have chosen to follow the Yoruba message with my own literal translation of the context in the English language. With this English version, I have killed two proverbial birds with one stone throw. Come with me as I deliver the message of Moyo Okediji, the Professor of Arts and Art History, from the University of Texas at Austin.

The book, which Professor Roland Abiodun, wrote should be rightly titled, "A person with a smelly or stinking or rotten mouth is still the rightful owner of his/her mother's water pot." Figuratively, the fact that a person has some 
shortcomings or some imperfections does not preclude him/her from being entitled to what belongs to the person by natural right. It is flabbergasting to realize that the English, the French and the Portuguese have attempted to tactfully, and unfairly, snatch away the African art with the use of their languages. As the Yoruba would say at such a time as this, "Without a good reason, a woman does not assume the status of the family superman." In other words, whatever has prompted the proverbial aging of the okra pod must be responsible for the reddening (that is, aging) of the garden eggs. By this, I mean whatever accounts for the reason the art of the Yoruba or even of other African ethnic groups are transmitted, critiqued or presented in the English language or in other European languages, demands explanations. I crave your indulgence touching on some of those explanations.

The fact of the matter is that it's not that we, the Yoruba people, do not have our clever ways of making discourses on our arts and crafts long before the advent of the Europeans on our shores. However, since their arrival, it has been with ardent determination that they have endeavored to forcefully take from us our right to use our language and/or languages in the process. Let us face it: it is impossible (for me as Yoruba) to think right in the English language. The use of the English language is a bumpy ride for the Yoruba who is on a journey towards the attainment of an authentic epistemology in their art and culture - one is bound to miss the road, fall into the ditch or bump into the mound, and compromise the authentic facts of the culture and the art of the people. In the words of the Elder, Awise Wande Abimbola, which he taught us in our youthful days, "We par together things that go together just as the shells of the peanuts give a resemblance to the casket of the diminutive rat." The plain English language is just not capable of unknotting or delivering the loaded Yoruba concepts that the artists tie together holistically in their works of visual, verbal, cognitive, and aesthetic configuration, and which together, are called the Yoruba art forms. Philosophically tied together just like the pieces of yams readied for presenting to one's in-law, how on earth could they be unraveled except through Yoruba language? Words uttered, regardless of its volume, cannot fill up the woven basket. No amount of poetic or prosaic rendition of the English language is capable of delivering, describing, or analyzing the Yoruba art.

Elder Lamidi Olonade Fakeye, of sweet memory, was the one who engaged me in an essentially deep philosophical discourse when we honored him with a book that I edited in 1988. As I presented the book to him, Elder Fakeye took a quick look at the book and giggled. Out of curiosity I asked him why. "Moyo, let me tell you the truth," said the elder; "truth is bitter but you Western-schooled elites are a bunch of intense, pathological liars!" "Elder, how come?" I asked in exasperation. The sage responded, "What the heck, Moyo! 
How come the one lending a helping hand is carrying more burden than the owner of the load? I am just a wood carver, carving the pillars to sustain the house. Who knows that the mere carving of the baobab tree (Adansonia digitata) would generate so much garrulous English utterances? Oh well, the hand-crafter has done his art, let the loose mouth begin its deeds." "Elder, I doff my hat with humble homage to your age and wisdom," was all I could say.

Elder Fakeye then opened the book as he held it in his hand and exclaimed, "How in God's planet earth does my work of art have anything to do with all the bombastic, dry husk English words that you have plastered across the pages of this book?" I responded by saying, "Well, in my mind, they seem to have things in common." The elderly sage then burst into an uproar of laughter. He then quipped, "Okay, tell me, how could any of these English words possibly be translated or translatable to the Yoruba language or speak to the Yoruba art?"

I did not think twice before I responded that, "It's no big deal; after all it's just a matter of translating them from English to Yoruba."

The elderly man responded by saying, "Moyo, it's not that easy. The English language has no resemblance to the Yoruba language. If the English language were to be capable of producing the Yoruba proverb at all, would it be capable of uttering incantations? What about code speaks, power utterances, words of enchantments and the guild of hunters' poetic invocations; talk less of the heroic poetry of the family lineage?" I quickly responded by saying, "It's all possible these days; after all in the United States, consultations with Ifa are now being done in the English language." Elder Fakeye asked pointblank, "If that is the case, then tell me how to say, "Ilee kaaaro, oo jiire" in the English language.

That was my eye-opener. I now realized the point the elderly man was trying to get across to me, knowing where he was headed, but oblivious of where he was coming from. Just as it's mere wishful thinking to imagine the Yoruba language becoming the English language, so it is an illusion to expect the English language to convey Yoruba concepts. The best we can see in that scenario is the metaphoric mask, not the masquerade, let alone the spirit, soul and flesh behind the veil.

First of all, language and culture are inseparable. Once one is out of the picture, what we have left is akin to the carved image of the twin; the blood and the flesh are gone - the soul is no longer present, only the mirage, not the objective reality. As Elder Fakeye noted, anyone analyzing Yoruba art with the English language has taken the soul out of the body; all that is left is at the very best gibberish. This is the declaration from the mouth of the consummate practitioner, Elder Fakeye. 
Secondly, every language has its secret codes, which the uninitiated is not capable of decoding. This is like a child confusing the leaves meant for herbal remedies as if they were meant for mere recreational consumption, soul food. The reality is this: the best the non-native user of the Yoruba language could get is minimal. The proverbial leaf of the language could be shown to non-native users; the actual leaf is hardly ever handed to them. Sometimes, they are handed to them, but the true name of the leaf is never divulged. It's the tale of the farmer who set out to the farm devoid of the hoeing instrument; he is found wanting if the field is grown! Why are we saying this? It is because the Yoruba language is a set of codes, spoken in codes, and heard in codes, just as Elder Abiodun, the author of this book, has said in this book. Elder Abiodun is saying in this book that it is a set of codes that has transformed itself into the Yoruba art and the art has given birth to unlimited discourses.

The fact of the matter is that when it comes to the English language and the Yoruba aesthetics, the mythical blacksmith is not capable of casting the sheet of paper, he can only burn it. The moment one opens the appreciation of the Yoruba art with the English language, one is entrapped. Let's go to the basics, like eating the black-eye pudding from its flat end: what exactly is the word for "art" in Yoruba? This plain question is no joke. First of all, it would seem like the simplest form of a question. We can say the word for art in Yoruba is "Ona." However, on a closer examination, this question is set-up to entrap the unsuspecting. This is not a real question; it is a snare. The ideal answer to such a trick question is "why should the Yoruba have a word for "art?" Has anyone asked the English people to give the meaning of the word "Igunnu" in English language? The moment one is asked to give the meaning of the word "art" in Yoruba, one is dumbfounded, confused and insecure, as if it is mandatory to have a word for art in our mother tongue. The question is, should every idea of the English have its welcome in the context of the Yoruba language when reverse is never the case for the English language?

What actually prompted this way of thinking is that the English people colonized the Yoruba people. I have deliberated chosen the word "colonized" in its borrowed form. What exactly does the word "colonize" mean in Yoruba. The word comes from the root word "colony." In essence the English people came to my father's farm and turned it into their "colony." It's like me looking at the cloth you are wearing and say, "this cloth belongs to Moyo." If this were to happen, you would look at me with bewilderment and ask, "Moyosore, are you drunk with the potent liquor of sekete?" But since the English man used the word "colony" drawn from their language to describe our fatherland, we did not get it right that our fatherland is no colony for their forefathers. Since all they said came straight from the grammar of their language, it was not long before they became "colonizers" (rendered in the Yoruba form), engaging 
in "colonization," and we, servants of God, becoming the "colonized." In fact, our scholars have started writing on "post-colonial studies" these days. This is nothing more than an intellectual deceit. This deceit would, however, take on the resemblance of truth when our thinking is based on the English construct. This is the logical explanation as to why the Yoruba should never think in the English language if we do not want to fall into the intellectual (and cultural) pit. Like the proverbial hoe, the English language can only drag the Yoruba art and culture in its own direction.

A great deal of conspiracy and self-serving have taken place in Africa regarding the imposition of the English language. They took a first look at the works and named them "primitive art." They wrote endlessly on their notion of the primitiveness of the African art. Paul S. Wingert (1977) and Douglas Newton (1978) wrote voluminous books to justify that the African art is "primitive." Later they admitted that it was wicket of them to conceive of African art as "primitive;" instead, they should see them as "tribal art." Jean-Baptiste Bacquart did a marvelous book on the so-called African "tribal" art, illustrating the notion with myriads of images. But that did not end it. At one point they decided African art should be conceptualized as "traditional art." In 1992, Elder John Picton provided arguments against the idea of referring to African art as traditional. However, his arguments were heard but not taken to heart, as they never cease to refer to African art as traditional. Some refer to it as historical art; some as classical art. It seems the confusion must have taken over among Europeans as to the nomenclature or christening of the African art, each one calling it as it pleases.

The astonishing part of it is that even African scholars began using the European perspectives to articulate their own art, forgetting their own indigenous languages of discourse, thinking outside the paradigm of the indigenous. They are content with whatever the Europeans prescribe as the way to analyze their art. It's like acting on the Europeans' prompting; after all, their speeches, and thinking and fads are essentially European, becoming pets for the European culture!

Not too long, Europeans now argued that there are certain artists in Africa who are totally different from the group they've christened "traditional" because members of that particular group were schooled in art. Apparently, many of them didn't even believe that those artists they classified as "traditional" ever went to school to learn art. Europeans then started to describe that group as "contemporary." When it suits them they referred to this group as modern. They would analyze them in their jaundiced fashion, an exercise in mediocrity and futility.

In all honesty, it's not always only out of evil intent that these Europeans have attempted to hijack our art. The fact of the matter is that an attempt to fix 
the unbroken art of our people often ends up as the proverbial mother monkey that attempted to fix the face of the baby monkey only to end up poking into its eye and disfiguring the baby's face altogether. This calls to memory my experience with the recently deceased Dr. John Pemberton III. I met the gentleman in 1984 in Ile-Ife, where he was engaged in serious research with the Elder (Abiodun). With endless snapping and clicking of pictures - left, right and center, Pemberton could be seen multitasking relentlessly. He climbed, stooped and squatted just to capture the right images, while simultaneously scribbling on paper, eliciting a plethora of information, and wiping off perspiration as he focused his attention on observing the master sculptor, Elder (Lamidi) Fakeye.

With ease and unabated satisfaction, the master sculptor Fakeye sat and worked with a smirk on his face and paying little or no attention to Elder Pemberton, who came all the way from the United States to conduct his research in Ile-Ife. On reading the article, however, it left the metaphoric taste of the unripened plantain in my mouth - unsavory in taste, uneasy to swallow. It was published in the book of a collection of images/pictures titled, Art and Oracle: African Art and Rituals of Divination. My first natural instinct is to query the meaning of the title of this book. I asked what exactly in genuine Yoruba were these concepts of artifact, rituals, and divination? There is no doubt in my mind that Dr. Alisa LaGamma, the editor of the collected images in book, and who is from Africa, I must add, was apparently thinking in the English language in his assemblage of these images. Clearly, every intellectual cultivation in this work was performed with the instrument of the Whiteman, (and the result was clear). From the beginning to the end, this book would miserably fail the test of intellectual quality when measured by the standard of the Yoruba language and culture. Concepts such as artifact, aesthetic qualities, ancestral spiritual realm, figurative and all significant concepts on the first page of the book were more than enough to give the stomach flu to a competent user of, and thinker in, the Yoruba language. What in the world, for example, is "Dynamic Devices: Kinetic Oracles?" They seem and sound like gibberishes of no redeeming qualities. All those so-called "Iconography, pluralistic vision, visual metaphor, human protagonists, abstraction, realism," and the remaining superfluous expressions have no place in the contexts of Yoruba commonplace expressions.

These are challenging issues that starred Professor Rowland Abiodun in the face, prompting him to come up with this book. Armed with the wisdom that a lack of knowledge of the future does not deny one of the existence of one's past, Abiodun challenges us that the tears of sorrow should not deny us the ability to see. We have our own language for appreciating our own art. Our scholarly teachers like the Elder Professor Olasope Oyelaran have taught 
us to write the Yoruba language with ease. How dare we then be disillusioned on this matter? Are we not aware that the Yoruba are endowed with proverbs, code words, songs, folktales, stories, divination chants, hunters' poetry and dirges, incantations, enchantments, invocations, and many more powerful oral traditions that are used to appreciate and interpret art forms? What then would account for the confusing and unacceptable concepts such as "primitive," "tribal," "traditional," "historical," "classical," "contemporary," "modern," and all sorts of unacceptable classifications in reference to our art forms? How come that Western scholars would be the ones to raise the chorus of our art and we are so eager to follow the refrain in the manner of ignoramuses? Elder Abiodun has insisted on putting the right bird on the right tree, arguing (with empirical evidence) that we cannot be silent or silenced by saying what we know is right about us, and which we are naturally crafted to be able to say. We are the proverbial child, who is the owner of a smelly or stinking or rotten mouth, one who goes about with a smelly mouth, but is still the rightful owner of his/her mother's water pot. The language and culture of Yoruba are together the mother that gave birth to our art. A child takes after the parents. That is why Elder Abiodun made the proclamation that "enough is enough!" The right water must be credited to the right spring. These are some of the many factors that prompted Elder Abiodun to produce this work that unquestionably has universal currency and global implications. He has done so through this book that has triggered the gathering of today. Elder Abiodun is not given to verbosity. This time around, though, necessity has compelled him to speak out, and he has done so with passion and unharnessed intensity. And there you have it! 